\title{
National belonging needs and natural historical cultural analysis of Chinese Manchu
}

\author{
Hui-Qi WEN* \\ School of Marxism Zhejiang University, Hangzhou, China \\ 383455625@qq.com
}

Keywords: Manchu, National belonging needs, Natural historical culture.

\begin{abstract}
National belonging needs are the logical starting point of exploring the natural history and culture of Manchu in China. It is also the third stage of Maslow's hierarchy of needs_—social needs, in other words, the belonging to the stable social organization. It formed steady-state social organizations and provided a sense of national belonging for clansmen, due to Manchu's uniqueness of religion, folk customs and culture and dominant position in the specific historical period. The spirit quality of steady-state social organizations also include: heroic and mighty national spirit of hunting, the brave and hardworking spirit of the collection activities and the alert and sapiential ethos of fishing. But Manchu gradually lost its national characteristics and dying, with the deep integration of Han nationality culture. Manchu's stable social organizations tend to collapse and national belonging needs are coming apart under the dual effects of natural factors and historical and cultural factors.
\end{abstract}

\section{The Basic Situation of Chinese Manchu}

Manchu is one of the 55 Chinese minorities. Manchu has had different names in different periods including Manchuria group, Manmin, Manren, and Manchu. In addition, different names reveal different periods of history. The earliest period of Manchu is Sushen in the Qin dynasty, after this, it also went through the period of Yilou, Wuji, Mohe and Nuchen. The updating of the national culture and the integration with China greatly promoted the improvement of Manchu culture. In A.D. 1616 (Ming Wanli year 44), Qing emperor Nur Ha Che unified Jianzhou Nuchen, Haixi Nuchen and Yeren Nuchen and established post-jin regime. Manchu formally established her regime in A.D. 1635 (Ming Chongzhen year 8). At the same time, the Qing emperor Huang Taiji formally established the title of Manchuria. In A.D. 1636 (Qing Chongde year 1), Huang Taiji officially named the nation name as Qing. In A.D. 1644 (Qing Shunzhi year 1), the Qing dynasty finally had its own regime. After the demise of the Qing regime, its title was changed from Manchuria to Manchu which is still used today. Manchu has its own language and writing - Manchu language and Manchu script. The Manchu language belongs to the Altaic language family and Manchu Tungusic language group, and its foundational language is Mongolian. The shape of Manchu writing presents vertical straight. All in all, Manchu language has greatly inspired feeling and cultural connotation. In the aspect of population distribution, the population of Manchu is unevenly distributed across China as a result of national integration and migration, historical culture, war and national policy. On the whole, the Manchurian people are dispersed. The largest concentration of Manchu people is in Liaoning Province of China. In addition, the Manchu people are widely distributed in the 31 administrative units in China, including Heilongjiang province, Jilin province, Liaoning province, Hebei province,, and Inner Mongolia. The below chart shows that the contrast between the Manchu population and the total population in China in different periods.

However, the concern is that there are few people who can speak and write the Manchu language among the nearly 10 million Manchu. At present, a portion of Manchus and Manchu language enthusiasts have already realized the crisis of the Manchu language's disappearance, and they are now vigorously disseminating the Manchu language and script by various media and means. Meanwhile, with regard to cultural construction in colleges and universities, many measures have been taken. Heilongjiang University has regarded Manchu research language as a key discipline; 
Harbin Engineering University held the Manchu-Tungusic language seminar in 2005; Northeast Agricultural University set up the Manchu language enthusiastic association in 2006; Professor Zhuang Jifa in Taiwan National Chengchi University offered the Manchu language course and published a couple of Manchu language monographs; Central Nationalities University also offered Manchu language classes to satisfy the needs of its enthusiasts in 2011. In addition, many measures have also been taken to rescue the Manchu culture in folk cultural construction. For example, Huanren Manchu Autonomous County in Liaoning Province offered Manchu language teaching throughout the county primary schools in order to promote the national language in 2012; the Manchu language schools gave lessons in the Manchu language for the students in seventh grade for the first time in May, 2012.

\section{The Rise of the Manchu and the Formation of National Belonging Needs}

\section{Shaman Religion and the Core of National Belonging Needs}

The formation of national belonging needs are the core driving force of stable social organizations. Shaman religion is the core of the national belonging needs. This is because it led to the formation of single steady - state organization of men and gods. The Manchu people believe in Shamanism whose key idea is animism as a folk belief. Shamanism deeply impacts both the physical and spiritual life of the Manchu people. Under the influence of animism, the Manchu worship culture included nature worship, totem worship and ancestor worship. Nature worship refers to the psychological phenomenon that makes the natural things turn into apotheosis and produces the worshiped psychological thought, such as mountains, fires, water, the moon, stars, wind etc. The typical representative of natural worship is a god whose worship is regarded as the most important one among all with the right of being in charge of everything in the universe. Furthermore, the objects of totem worship refer to the animals and plants. These include eagle worship, willow worship and others. Finally, the Manchu forefathers originated the Changbai Mountain areas in Jilin province in China, and they have the deep emotional connection to the mountain. Changbai mountain worship is a typical representative of ancestor worship. Shaman religion is the core of the national belonging needs. Moreover, it is also the guidance of the spirit of hunting mode of production, and gradually extends to organization of men and men from organization of men and gods.

\section{Hunting Creates a Heroic and Mighty National Spirit}

The Manchu ancestors' hunting activities are provided with organization and discipline, and they also had strong consciousness of teamwork and cooperation. Collective hunting mostly regards the dan or village as an organizational unit, which is lead by the chieftain of hunting (called "abuda" in Manchu) who is responsible for the organization and allocation. After hunting, according to the Manchu tradition, they must worship the hunting god together, called bandamafa in Manchu language. At last, they will come back under the hunting leader. The hunting activities became more standardized under the Eight Banners System. The Manchu ancestors divided the hunting mountains into several parts, then gave one to each banner. Bear hunting was a typical activity for the Manchu. Because bears have a lot of energy and lethality, Manchu ancestors regarded the persons who can hunt for bears unarmed as heroes. In the aspects of hunting for bears, the Manchu ancestors had their own methods and behaved bravely, which is also the basis for the military struggle. The best season for bear hunting is the winter. There are two reasons for this: first, bears hibernate in the winter which makes them easy hunting; second, the cold winter weather makes the bears' paws and galls more fresh. There were two methods of hunting for bears in winter: the first one is to hunt for bears in the hollows; the second one is opposite for getting them by expelling the bears climbing out from the tree holds. The second method requires a higher hunting skill, because the bear-hunters must hit the right moment to hunt them. Being too early or too late will both bring trouble and danger to hunters. In addition, hunting for eagles is also a typical activity in Manchu society. However, it is really different from the bear hunting. The eagles are the helpers with 
Manchu hunters. After capturing the eagles, the hunters will start their special training to get the eagles more meek until they always are obedient to the hunters. The eagles are called "HaidongQing" in Manchu. Their appearance is handsome, their actions are alert, their energy is huge and their claws and beaks are sharp. However, hunting for eagles is not an easy thing to do, for it has a high requirement of experience, patience, insight, memory, etc. In fact, these factors are also essential ones in the military activities. The Manchu ancestors gradually formed a complete eagle-hunting system, including hunting eagles, training eagles, using eagles and releasing eagles. After they entered into the pass, the Manchu people obtained the traditional culture of riding and hunting, which was not only the symbol of Manchu spirits, but also the inheritance of it. Mulan paddock is the best example. In 1681 A.D. (the 20th year under the reign of Kangxi in the Qin dynasty), the emperor Kangxi set the hunting grounds about ten thousand square kilometers in the northeast of Hebei province, in order to train the military power of the nobles and the soldiers under the eight banners system. According to statistics, during the period from Kangxi to JiaQing, there were activities held 105 different times for the purpose of riding, hunting and leisure in Mulan paddock. Thus, it can be seen that the culture of riding and hunting played an important role in Manchu history.

\section{The Collection Activities Created the Brave and Hardworking Spirits in Manchu society}

Manchu ancestors had a close bond with the sea, and they wrote a series of glorious chapters in Chinese maritime history. Picking pearls is a representative activity in Manchu collection activities. Manchu ancestors called them "north pearls" or "east pearls," and this is called nichuhe in Manchu language, representing brightness and happiness. The Manchu ancestors lived near the seas and rivers, whose "east pearls" had fine texture and white, fruity features. In the long process of productive labor, the Manchu ancestors summed up a set of unique and practical methods for harvesting pearls. Pearling time was generally set at lunar April to August. The Manchu would come to the water's edge by canoes in large numbers to pick pearls in a set time each year. In fact, picking pearls was very hard, because the harvesters must dive into the water to fish mussels, and then take a breath to go on. These actions were repeated until their baskets were filled, and then they would swim back to the shore, giving the full harvest to the women and children who waited. They would then warm up on the shore, and then dive into the water again. The women and children on the shore were responsible for the process of shucking the mussels. They would pick them one by one to find pearls. Because of the hard shells of the mussels, injuries were common. Although pearling activities were very hard and dangerous, the Manchu ancestors always insisted on it. The brave and hardworking ethos was the guarantee of the Manchu social's continuation and development.

\section{The Fishing Culture Created the Alert and Sapiential Ethos in Manchu Society}

The alert and sapiential ethos was related closely to the fishing culture in Manchu society. Fishing culture played an important role, and for that, the Nurhachi set up specialized agencies to manage the local fishing general affairs. During the process of fishing, Manchu ancestors conducted it by organizational units. This form could not only improve the fishing efficiency, but also increase the number of fish caught. Manchu forefathers regarded a "purse net" as a unit. Seven people controlled one purse net, with one of them acting as a fishing leader. The fishing leader not only had rich fishing experience, but also possessed prestige in the clan. During the long history of fishing, Manchu people accumulated a set of fishing experiences, which was not only the living wisdom in Manchu society, but also an integral part of Manchu culture. Manchu ancestors usually conducted fishing activities in the spring, autumn and winter, according to the factors of solar terms, production experience, etc. Spring was a season of recovery. At this time, which was the best time to fish, stocks of fish were upstream in large numbers after experiencing a long winter. Manchu ancestors seized the opportunity, eventually returning with a haul. Through the whole fishing process, the role of fishing leader was crucial. The leader of fishing would find the fish in a centralized place, and then lead the whole clan to build dams with stones in order to prevent the loss of fish. Under the joint efforts of the tribe, they caught the fish together. Autumn was the harvest 
season. At this time, the fish, such as the sturgeons had fat bodies and delicious flavors. Every autumn, large numbers of salmon would be back to the rivers against the current in droves from distant Tatar Strait, in order to spawn. Manchu ancestors would cut the caught fish into fillets and dry the fish for storage. In addition, in order to eat fresh fish, they made the round logs into troughs filled with water to feed fish. Sturgeon and salmon were prized fish. Manchu ancestors raised them in captivity in the rivers, fencing them by wooden sticks, to prevent them from wandering. At the time of paying tribute to the imperial court, the Manchu ancestors would transport these prized fish by large tankers, constantly changing the running water, in order to keep them fresh. These methods of transporting fish and storing fish reflected the flexible and intelligence of the people. In the winter, everything was covered with snow and ice, and the weather was extremely cold. But the industrious Manchu ancestors did not stop the pursuing footsteps of material wealth. In contrast, they summarized a set of fishing methods through the weather features and the fishing habits. In the winter, the Manchu ancestors would beat the frozen rivers away to form ice cortex subs, then directly capture the fish with steel forks and fish hooks, making use of the phototaxis of the fish.

\section{The Disappearance of Manchu and the Breakdown of National Belonging Needs}

\section{Natural Factors}

\section{Influenced Deeply by Farming Culture}

The changes of production and lifestyles; With the destruction of the Ming dynasty and the establishment of the Qing dynasty, the mode of production and lifestyles in Manchu society had changed a lot because the Manchu had become the ruling nation. After that, they basically did not engage in agricultural production, or even their traditional fishing and hunting production. Breaking away from the natural environment, the natural basis which supported the Manchu national characters and the national temperament had disappeared .Moreover, in terms of social organization, the Manchu implemented the eight banners system. Within the framework of this system, banner men carried on productive activities in peacetime, and became soldiers in the wartime. The production activities said here did not mean the real basic production, for the high positions and important rights. The traditional riding and hunting activities only propagated down by the way of entertainment without the desire to conquer and fight. Comfort and depravation gradually corrupted the national life and spirit.

The conversion of national characters; In the period of feudal society, the significant features of agricultural production was autarky, but lacking communication with the outside world Most farmers only set eyes on their own small pieces of farmland, and gradually formed the short-sighted and narrow-minded characteristics. The crops only were eaten by the farmers, without the pursuit of the production tools and technological innovation and enhancements. Compared with farming, Manchu fishing and hunting activities usually appeared by cooperative forms. They helped each other, congregated wisdom and developed together. Thus, Manchu people gradually enhanced their national unity and sentiment. But the short-sighted, narrow-minded and separate characters in central plains farming culture virtually corrupted Manchu national characteristics.

\section{The Subtle Changes between Man and Nature}

In the period of fishing and hunting in Manchu society, the relationship between man and nature was generally made up of conquest and awe. Harsh natural environments let them dare to challenge and not be afraid of danger. In order to get the necessary material productive means, Manchu ancestors had to ask for nature to sustain the nation's development. The Manchu people asked for the nature within the rational range, and carried a thankful heart of nature in the process of conquest. The Manchu people believed in shamanism, with the strong idea of animism. Just for this, they would worship the gods after hunting to show reverence. After the establishment of the Qing dynasty, the Manchu living environment and conditions had been improved. The social roles also changed from hunters to rulers. Based on the above factors, the relationship between Manchu people and nature certainly changed a lot. The central plains agricultural production mainly relied 
on the land and weather. Different from the traditional fishing and hunting, these two factors were not decided by human resources. The Manchu people increasingly relied on the nature. The excessive dependence and obedience gradually wore away the national edges and corners. The Manchu rulers held casual and lazy attitude to the state and foreign affairs.

\section{Historic and Cultural Factors}

\section{The Impact of “Moderation Culture” as the Representative of Chinese National Culture}

Moderation culture is a core of traditional Chinese culture, which has a long history of development. It has a significant impact on Chinese politics, economy, cultural development etc, especially on Chinese mentations. Moderation culture had been accepted by rulers in the Han dynasty, and became the official ideology. Dynasties of rulers developed it and used it in practice. After the Qing dynasty entered the Shanhai pass, the Manchu people had to integrate into the cultural trends. With the passage of time, the Manchu society had totally accepted the moderation culture, and diluted their own cultural traditions. The mean thought possesses the representative characteristics in the moderation culture. The longtime of agricultural production shaped a series of agricultural characteristics: honesty, obscurity, kindness and so on. At the same time, some disadvantages also had been gradually revealed: selfishness, narrow vision, excessive patience and lack of responsibility. First, the state and foreign affairs also embodied the doctrines of the mean thoughts. Secondly, facing the foreign aggression, the attitude of the Qing government was endurance. Excessive endurance not only could not stop invasion steps, but also made the Qing empire lose face and face humiliation. A series of unequal treaties accelerated the steps of carving up China. On the other hand, these narrow agricultural characteristics also had some negative influence on the formulation of Qing dynasty's policy. In the 18th century, the uprisings from various regions quickly increased. The Qing dynasty began to implement the policy of avoiding contact with other countries, which was the typical representation of a narrow agricultural character. The Qing dynasty trapped itself in a cage, without listening to any advice from the outside and cutting off all economic, political, and cultural exchanges. This must be definitely abandoned by the world. Thirdly, the Qing rulers were selfish and lacking of responsibility. The uneven distribution of benefits inevitably led the people to rise up. The Qing dynasty fell into the internal and external dangerous situations.

\section{Spiritual Cultural Imbalance}

A strong and enduring country must rely on the national identity of all the people. Both the ruling class and ruled class need a national identity. The national identity is a necessary concept superstructure of the stable nation. If any class lost national identity, there must be destabilizing factors which will affect the national stability and endurance. National identity should include two aspects: the ruling class has responsibility for the subject; and the ruled class has the feeling of identity and belonging to the state. In the late period of Qing dynasty, there was a serious lack of national identity, which was the important cause of the decay of the Qing dynasty. From the aspect of the ruling class, the Qing government led by Cixi suppressed the uprising people inside and compromised to the aggressors outside. The Qing dynasty bullied the weak and feared the strong. The Sino-Japanese War broke out in 1894 deepened the Chinese semi-colonial degree. The Qing government suffered a defeat and sighed the humiliating "Treaty of Shimonoseki" under the pressure of Japan. It can be said that Qing rulers had totally discarded the bounden duty to the subjects, and gradually went down the road of destruction. Speaking from the ruled class, the weak and competent rulers made their people lived in an abyss of misery. People even could not breathe under the two mountains of imperialism and feudalism and their life could not be guaranteed with a serious lack of national identity. A series of peasant uprisings occurred: White Lotus Rebellion, Tenrikyo Uprising, Taiping Rebellion, Boxer Rebellion and so on. The spate of uprisings brought heavy losses to the Qing government. The distance between the Qing government and their people continued to increase.

The steady state of Manchu social structure collapsed consequently, with the natural historical 
cultural of Chinese Manchu and a strong sense of national identity.

\section{References}

[1] Information on http://www.stats.gov.cn/tjsj/pcsj/

[2] Information on http://www.seac.gov.cn/

[3] Huang Fengxiang. The state council approved the establishment of three new Manchu Autonomous counties: xiuyan,fengcheng,xinbin.[J].Chinese National.1985(4).(In Chinese)

[4] Wang Yuanqing. The thinking about the accelerated development of Manchu population.[J].National unity.1994(5).(In Chinese)

[5] Ge jianxiong (editor in chief).Population history of China.[M].Shanghai: Fudan University press.2005.(In Chinese) 